\title{
THE EFFECTIVENESS OF ONLINE TICKET MANAGEMENT BY VOLUNTEER IN GREBEG SURO 2018 AND REYOG PONOROGO NATIONAL FESTIVAL XXV
}

\author{
Yusuf Adam Hilman ${ }^{1}$, Irfan Nugroho ${ }^{1}$ \\ ${ }^{1}$ Universitas Muhammadiyah Ponorogo \\ Jl. Budi Utomo No 10, Ronowijayan, Siman, Ponorogo, East Java, Indonesia \\ Correspondence Email: 545471adamongis@ gmail.com
}

Submitted: November 26, 2019, Reviewed:May 06, 2020, Accepted: May 17, 2020

\begin{abstract}
Reyog Ponorogo National Festival (FNRP) is a national-level tourism agenda that is annually held in Ponorogo Regency, within the past 30 years, the Festival has begun to be improved in the right direction, deficiencies that have emerged, was tried to inventory and then improved, right at the holding of the Reyog Ponorogo National Festival (FNRP) in 2018 the committee developed a Voluntary Volunteer idea where volunteers were tasked with helping the agenda run smoothly, one of which was managing online ticket sales. This research used descriptive qualitative type, with the model of determining informants using purposive sampling, and data validity testing through triangulation. Online ticket management by Volunteer Grebeg Suro in organizing Grebeg Suro 2018 and the Reyog Ponorogo National Festival XXV could be concluded as effectively way. This was proofen from the respondents' assessment of the results of interviews that had all been expressed positive attitudes. Online tickets for Grebeg Suro and Reyog Ponorogo National Festival were considered to be very effective in organizing Grebeg Suro and Reyog Ponorogo National Festival events. Some assessment indicators were based on the time spent, the convenience provided, and the education provided to the community.
\end{abstract}

Keywords: Ponorogo Reyog National Festival (FNRP), Online Ticketing, Voluntary

\begin{abstract}
ABSTRAK
Festival Nasional Reyog Ponorogo (FNRP) merupakan agenda pariwisata di tingkat nasional yang diselenggarakan tahunan di Kabupaten Ponorogo, dalam kurun waktu 30 tahun terakhir, Festival mulai berbenah kearah yang lebih baik, kekurangan yang selama ini muncul, coba di data dan kemudian diperbaiki, bertepatan pada Festival Nasional Reyog Ponorogo (FNRP) di tahun 2018, panitia membuat sebuah gagasan kesukarelawanan (Volunteristic), dimana para relawan bertugas untuk membantu penyelenggaraan agenda tersebut supaya berjalan dengan lancar, dengan mengelola penjualan tiket online. Penelitian ini menggunakan jenis deskriptif kualitatif, dengan model penentuan informan memakai purposive sampling, dan uji keabsahan data melalui trianggulasi. Pengelolaan tiket online oleh Volunteer Grebeg Suro dapat dikatakan efektif. Hal ini dibuktikan dari hasil penilaian informan terhadap hasil wawancara yang telah dilakukan menyatakan sikap positif dalam penyelenggaraan kegiatan Grebeg Suro dan Festival Nasional Reyog Ponorogo. Beberapa indikator penilaiannya antara lain : berdasarkan waktu yang di keluarkan, kemudahan yang di berikan, dan edukasi yang di berikan kepada masyarakat.
\end{abstract}

Kata kunci: Festival Nasional Reyog Ponorogo (FNRP), Tiket Online, Volunteristik

\section{BACKGROUND}

The National Reyog Festival

(FRN), since 2016, has officially transformed into the Reyog Ponorogo National Festival (FNRP), the festival is an annual agenda in a series of tourist agendas 
Vol..6, No.1, 2020

Doi: https://doi.org/10.24198/cosmogov.v6i1.24793 http://jurnal.unpad.ac.id/cosmogov/index

entitled "Grebeg Suro" organized by the Government of the Regency of Ponorogo, FNRP involves many people. The event reminds us that it is a national-level tourism agenda and regarded as cultural activity, so it requires the involvement of many parties.

Reyog Ponorogo art contingent who participated in the activity, came from all over Indonesia, came to show each other ability to perform Reyog art. Of course this is the momentum awaited by the actors, activists, and observers of culture, especially Reyog art, but until the age of 24 in 2017, the committee realized that there were still many shortcomings, so it needed to be improved.

Real effort is needed to improve the organization of events so that they became better. Departing from the evaluation of the implementation of the festival the previous year, then proceed with making an improvement plan, with the hope that later national-level events could be held professionally.

Ponorogo Regency has various tourist attraction among others such as natural tourism, religious tourism, and cultural tourism, which recorded about 32 attractions, the potential is not yet optimal in its development, this is verified from the Regional Original Revenue in the tourism sector that reaches 800 million / per year. This condition indicates that there are still problems related to the development of the tourism sector, which is still centralized in the reyog event series, so that it has not yet touched on what is meant by tourism development both professionally (Kusbandrijo, Tjahjono, \& Rochim, 2018).

Reyog Ponorogo National Festival was held because of the decline in youth's interest in preserving Ponorogo Reyog Art, besides the socio-cultural traditions of the Ponorogo Regency people who still carry out the tradition of welcoming the Syuro month (Grebeg Suro) which was the reason for the implementation of the activity (Rismayanti, Marjono, \& Umamah., 2017).

The Reyog Ponorogo National Festival has been held 26 times, besides the Mini Reyog Festival has been held 17 times, but it is still far from the expectations of the community, we hope that there will be more participants, this is important considering one of the cultural activities supported by the Indonesian platform, has prerequisites for community involvement in greater numbers (antaranews.com. 2019).

Observing the evaluation of the Reyog Ponorogo National Festival from year to year gave an illustration, about the lack of participation or participation from the surrounding community, to help organize the activities, especially those related to technical activities in the field such as ticket sales and distribution.

The role of youth in the previous committee was very minimal, before the Voluenteer idea emerged, this was due to the involvement of the committee, involving only local government officials, so that the community or youth were not so enthusiastic (Agung, 2019)

The committee which has been in the form of the majority of its members was taken from the Ponorogo boys and girls contest which is commonly called Kakang - Senduk, this also causes less enthusiasm (Nugroho, 2019).

Social movement, with a nonprofit style, is a movement that seeks to 
Vol..6, No.1, 2020

Doi: https://doi.org/10.24198/cosmogov.v6i1.24793

http://jurnal.unpad.ac.id/cosmogov/index

awaken many people to move the wider community to participate and be actively involved in the activity. The action is a social activity volunteerism link between individual by individual, in a useful activity for the (Ramma Wisnu Dewantara, 2015).

Concrete steps undertook by the administration Regency Ponorogo by forming the committee to improve the performance of the organizers of the Reyog
Ponorogo National Festival, to help the execution of a task (Azrina Mazlin Alias, 2016)

Voluenteristic is usually drawn from youth who are active in various social activities, economical even as done by the Ponorogo Regency to revitalize the tourism sector.

Figure 1. Open Recruitmen Volunteer Grebeg Suro 2018

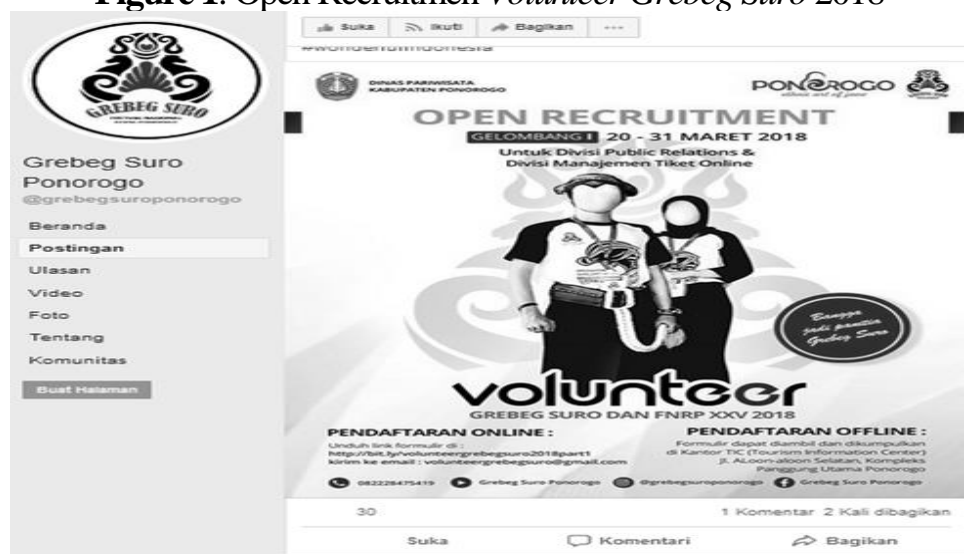

Source: Facebook Grebeg Suro Ponorogo

They are individuals who freely contribute their services, without remuneration, to a public or voluntary organization engaged in all types of social welfare activities. The fields of service include family and child welfare, education, health and mental health, recreation, community development, housing and urban renewal, and correction.

That concept seems to illustrate that the activity of voluntaristic had four roles: as the agent of change, namely the field agents, the consultants, the advocate, and social planner (planning) (Iwan, 2012).

The role of youth as volunteers had greatly influenced the activities of the Grebeg Suro organization, where many young people participated in the committee, eventually leading to various inputs, ideas and innovations in organizing the event.

Youth participation is more dynamic and follows the development era, makes innovation appear to go with the harmony with technology development, where this event from Reyog Ponorogo National Festival, an idea related to the utilization of technology information, has been adopted to do the human duty mainly to simplify the responsibilities of the volunteers.

A case study in the Reyog Ponorogo National Festival raised hopes that these activities can bring innovations to the use of information technology in the event. 
Vol..6, No.1, 2020

Doi: https://doi.org/10.24198/cosmogov.v6i1.24793 http://jurnal.unpad.ac.id/cosmogov/index

Information and communication technology (TIK), according to The ministry of research and technology in 2006, is all related to the technology, the collection, processing, storage, distributing, and presentation of information (Indonesia, 2006).

Information technology can facilitate human activities, government activities, including easier and effective. Data of the government first processed manually, then touch technology into a systematic, data neat, and developed.

One aspect of supporting Information and Communication Technology (ICT) is the internet. Internet access is very important because most interactions can only be done using internet access. With the internet we can interact with anyone, anytime and anywhere online. Through an online system many things can be done easily. Starting from news, television channels, radio channels, school registration, selling to buying goods can all be done online.

The development of information and communication technology has triggered the government's desire as a public service provider to try to innovate by developing the concept of Electronic Government (e-Gov) which is used by the government in providing services in all fields to the public. The implementation of $e-G o v$ in Indonesia is supported by the Presidential Instruction Number 3 of 2003 concerning National Policies and Strategies for e-Government Development. The government utilizes e-Gov for services in the fields of economy, health, tourism, education, transportation, and others.
Public services are all forms of goods or services, both in the context of efforts to meet the needs of the community and in the context of implementing statutory provisions (Mutiarin, 2014).

The effectiveness of basic were elements to accomplish a purpose or target that has been specified in any organization. Effectiveness is also called effective if the achievement of goals or objectives that have been determined. Soewarno points out that the efficacy of the achievement measurement of the aims is in the sense of having been previously decided (Zaenudin, 2014).

Mahmudi argues that effectiveness is the relationship between the output by the more considerable contribution to the achievement of a goal, output the more effective, organization programs, or activities (Mahmudi, 2005).

Siagian mentioned is that the effectiveness of the utilization of natural resources, facilities, and infrastructures to a specified amount, which consciously set forth beforehand to produced some goods or services activities that run (Siagian, 2001).

The opinion above emphasizes the achievement of a goal. A thing can be said effective if rise to an effect or impact on what is wanted or expected.

Information systems is a system in which there is, the organization where within those systems will confront management needs to implement, of daily transactions to support the implementation of the operational or, and made arrangements in the tactical report in the form of administration (Jugiyanto, 2005). 
Vol..6, No.1, 2020

Doi: https://doi.org/10.24198/cosmogov.v6i1.24793 http://jurnal.unpad.ac.id/cosmogov/index

Online tickets are a new breakthrough made by Volunteer Grebeg Suro in providing effective and efficient services to the public. With online tickets, people can easily get FNRP tickets, 24 hours a day and during this activity, wherever and whenever, to buy online tickets, can directly enter the Grebeg Suro application which can be downloaded at the Google Play Store.

E-ticketing is a way to the selling process of document activities - say that without having to sell released a document physically. All information on electronic ticketing kept digitally in system computer for very simple, and the E-Ticketing (ET) may present opportunities to minimize the cost, through it, the if compared with the offline ticket, like coupons, ticket, Spent a lot of paper (Sekapur, 2009).

The background of the application of these online tickets is to make it easy for people to get tickets FNRP and reduce long queues at the counter to discomfort visitors. A thing for the establishment of a system online in the ticket sale is the lack of clarity regarding the information given to the number given.

This application-based online ticket, makes people easier to get FNRP tickets, because currently buying tickets does not have to go to the counter in Ponorogo Regency Square. Volunteer Grebeg Suro provides services for ticket purchases through many reservation channels with various payment options, in addition to that tickets can be booked in advance, so that it no longer disappoints visitors because they run out of tickets.

From several studies that have been done, it can be seen that the use of online tickets, in an organizational system is considered to be very effective and efficient.

The research results on the effectiveness of online tickets application based on the Rail Ticket System (RTS) at PT. Kereta Api Indonesia (Persero) Regional Operations 8 Gubeng Surabaya shows quite effective with a percentage value of $61 \%-80 \%$, system quality by $76.6 \%, 79.2 \%$ for information quality, $76.6 \%$ for service quality, $80 \%$ for users, $79.6 \%$ for customer satisfaction, and $77.3 \%$ for net profits (Siagian I. C., 2014).

Andri Alphonso's research results (2019) about: "Effectiveness of electronic ticket payments on the Trans Padang Bus" can be said to be quite effective, referring to the measurement of effectiveness proposed by Campbell, which includes, several indicators: program success, target success, satisfaction with the program, level inputs and outputs, achievement of overall goals (Alphonso \& Eriyanti, 2019).

The results of the study of Ni Putu Ayu Wangi Diantini, Sukidin, Wiwin Hartanto (2019), shows that: the effectiveness of the mobile application "KAI ACCESS" by PT. Kereta Api Indonesia (Persero), Railway Station Jember Regency", can be said very effective (Diantini, Sukidin, \& Hartanto, 2019).

A new breakthrough in the implementation of the FNRP tourism agenda, ideally through the use of information technology does look easy to do, but when practiced in the field, sometimes it always causes various problems, because many things sometimes appear to be problems or obstacles, 
Vol..6, No.1, 2020

Doi: https://doi.org/10.24198/cosmogov.v6i1.24793

http://jurnal.unpad.ac.id/cosmogov/index

whereas innovation in related systems $E$ Ticketing management in the tourism agenda, is expected to be able to solve the problem that has been a homework for managers in charge of organizing the tourism agenda so that it can run well, professionally and bring positive impact to the community.

Government intervention social does some to improve practices community development at the village level. Social intervention in this context was the village community directed at the creation of innovation (Suhendra, A., \& Setiaputra, I. R. A. (2019).

Regional innovation is a follow up of a program or activity in each area. Regional innovation programs are based on Law 23 of 2014 concerning regional governance. Regional innovation mentioned in Article 386 paragraph 2 that Regional innovation is all forms of renewal in the administration of Regional Government.

\section{METHOD}

The methodology is a scientific way to get data with purpose and specific use (Sugiyono, 2010) The kind of research utilizes descriptive qualitative research techniques in collecting data using, documentation, said. Image. Data obtained from in-depth interviews, notes, the text, report, and documents other he official interconnected and associated with research performed with the theory of bottom to top (Moleong, 2014).

Research setting is a place where research will be conducted to obtain data or information related to research. The research was carried out in Ponorogo
Regency, because Ponorogo Regency is an area that organizes the Sureb Grebeg and Ponogogo Reyog National Festival.

Informants were chosen and determined based on the characteristic of particular considered relevant to the object research. Informants known overconcerned to the social conditions will examine in this research.

Informants are chosen in this research is the 5th people who a Volunteer, Grebeg Suro 2018 and Reyog Ponorogo National Festival XXV. Informants are selected in this research is the 1st heads. 1st people, the coordinator. 1st coordinating online ticket, 1st member division online ticket; 1st heads of managerial division online ticket.

Test the validity of the data used the technique triangulation. Researchers Triangulation technique used to check the data from various sources in various ways and at different times.

The technique used in this research is qualitative descriptive analysis, with the procedure or how to solve a problem in a study through exposure to the object's condition in accordance with actual facts (Nawawi, 2003).

Descriptive qualitative techniques are more specifically using an interactive model that is data reduction, data presentation, and finally drawing conclusions (Sugiyono, 2012).

Triangulation technique is a technical examination of the validity of the data, tap something else out data, and to checking or in comparison of the data. There is four kinds of triangulation as a technique of the use: source, method, investigation, and theory. 
Vol..6, No.1, 2020

Doi: https://doi.org/10.24198/cosmogov.v6i1.24793

http://jurnal.unpad.ac.id/cosmogov/index

This research used technique, which means comparing the triangulation and checking whether belief in a degree of information obtained through time and a difference in the qualitative method. It was collected by researchers using:

Compare data observations with data interview. They are comparing what others say in public with what is said in private.

Comparing what they of regarding situations research with the what is said all the time. Compare a person with various opinions and views well educated, and he was the government.

Comparing the results of interviews with the contents of something document that is concerned (Sugiyono, 2010).

After the process of the data processing was done, then in carrying on with test the validity of, data through triangulation, a source where crosscheck researchers conducted by displaying various sources so it looks obvious generalization that will emerge from the data is processed, can all accounted for and legitimate

\section{RESULT AND DISCUSSION}

\section{Distinction tickets online and offline}

Management was the main difference between online and offline tickets. Online tickets were sold through the Grebeg Suro 2018 application which could be downloaded at the Google Play Store app for free, there were features with a variety of package options and prices, while offline tickets are sold directly at the stand which has been provided by the committee at the venue of the event, the benefits of an online ticket was we did not have to wait to queue to buy a ticket, other than that the buyer could also choose the ticket category according to the desired seat, in addition there were additional facilities when the buyer ordered an online ticket that was getting a goody bag of course, according to the type of ticket booked.

The innovation made was the process of changing from print ticket management to e-ticketing which showed the changes in form here, it could be seen how the characteristics of tickets were very different, besides being more effective online tickets were easier to control their distribution, so the monitoring process becomes easier.

Figure 2. Application Online Tickets

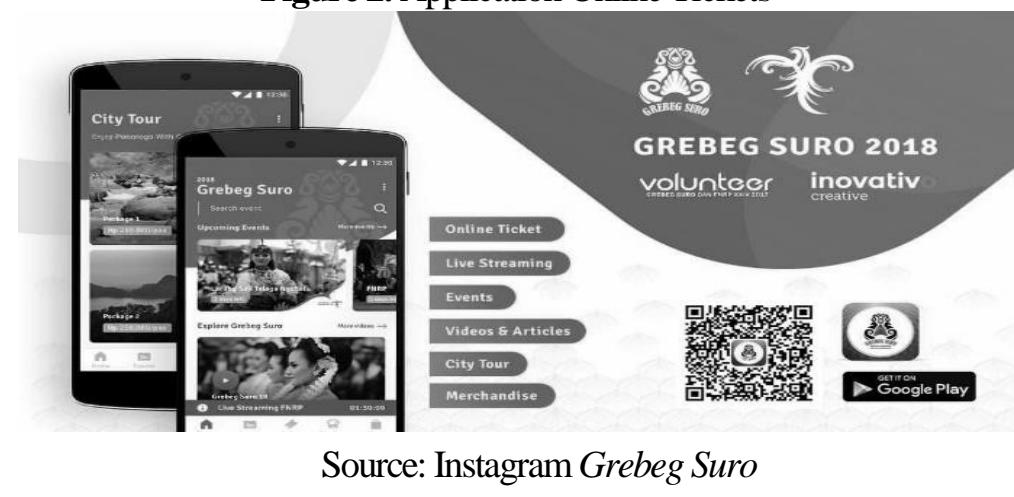


Vol..6, No.1, 2020

Doi: https://doi.org/10.24198/cosmogov.v6i1.24793

http://jurnal.unpad.ac.id/cosmogov/index

Figur 3. Online ticket applications with an options package

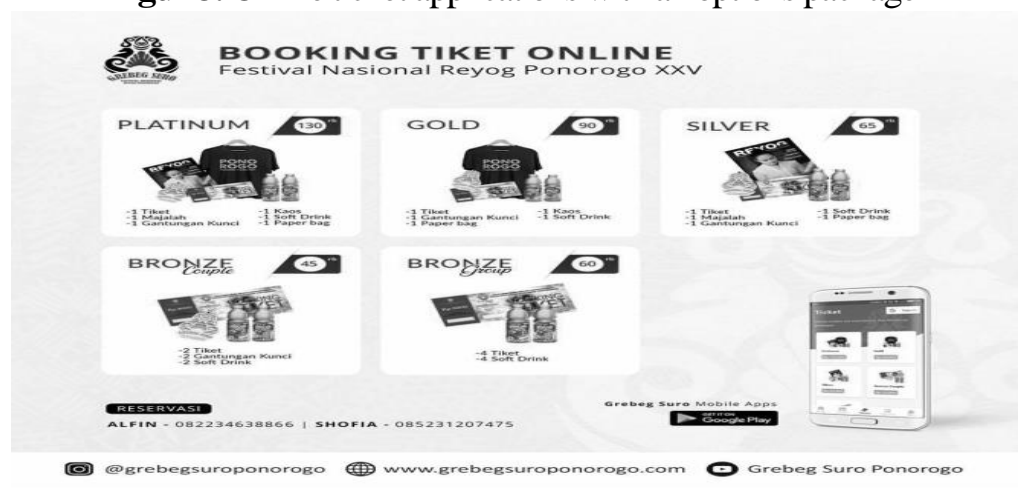

Source: Instagram Grebeg Suro

\section{The development of Online Tickets}

The development of online ticket management when compared to 2017 with 2018 so it could be seen that there was an increase in the number of buyers. It could be seen from the purchase of tickets in 2017, only about 150 reservations, but in 2018 it increased to 200 reservations per / day. In 2017, when online tickets were introduced with a vulnerable time of ordering 8 days, tickets were sold for \pm 850 seats, whereas in 2018 with 4 business days sales reached \pm 950 seats, indicating that the online ticket sales system became very effective.

In general, the online ticket Grebeg Suro and FNRP were very rapidly got better. In terms of human resources management committee, financial management, marketing operational, and from time to time has in fixed up to provide proper qualities too and quantity of tourists who bought tickets to the online, And, the level of community satisfaction who bought tickets to the online went quite well.

Figur 4 Online Ticket Reservation Division Committee Structure

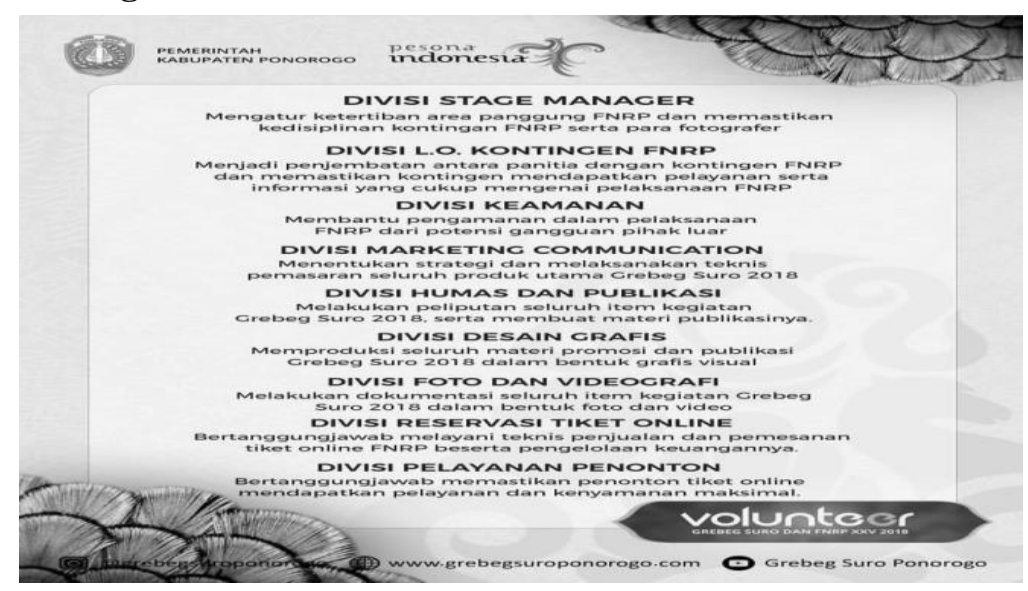

Source: Instagram Grebeg Suro 
Vol..6, No.1, 2020

Doi: https://doi.org/10.24198/cosmogov.v6i1.24793

http://jurnal.unpad.ac.id/cosmogov/index

Table 1. Online ticket sales management

\begin{tabular}{cccccc}
\hline & \multicolumn{3}{c}{ PROFIT ONLINE TICKET } & & \\
\hline VARIETY & PROFIT & QTY & \multicolumn{2}{c}{ SUM } \\
Platinum & Rp 6.774 & 28 & Rp & 189.672 \\
Gold & Rp 6.774 & 66 & Rp & 447.084 \\
Silver & Rp 6.774 & 8 & Rp & 54.192 \\
Bronze Couple & Rp 8.548 & 220 & Rp & 1.880 .560 \\
Bronze Group & Rp 14.980 & 89 & Rp & 1.333 .220 \\
& TOTAL & & Rp & $\mathbf{3 . 9 0 4 . 7 2 8}$ \\
\hline
\end{tabular}

Source: Estimated from research conducted

Innovation in the management of e-ticketing had also shown how the online ticket in governance, in the present with various option packages, then disseminated became more effective as it spread out over a wide through the application of which had been available.

The effectiveness of online ticket event of Grebeg Suro and FNRP

Online tickets were considered quite effective in organizing activities, if viewed from the assessment indicators, among others based on: time spent, convenience provided, and education provided to the public.

Online tickets through the Grebeg Suro application were able to provide good information about the products offered. Most online ticket viewers were those from outside the city.

Compared to the conventional ticket model E-Ticketing was very effective, due to complaints from visitors who had difficulty buying tickets and watching live, could make reservations without time limit.
Response of the society about online ticket

Various public responses to the existence of Grebeg Suro and FNRP online tickets were exposed. Not a few tourists or spectators who positively appreciated the Grebeg Suro application as well as the online ticket booking feature contained in the application. They felt no need to fret because they have to queue. Online tickets themselves were considered very practical and efficient, so it was very useful for those who did not want to be "complicated".

Management online by a Volunteer ticket

Online ticket management for Grebeg Suro and FNRP was very good, full of responsibility and totality. This was because it was managed by young people with fresh thoughts, advanced, and full of innovation.

The innovation was felt to be very appropriate amidst the problems that were often experienced in a few moments of organizing the tourism agenda in Ponorogo Regency.

The development of Grebeg Suro online tickets and the Reyog Ponorogo 
Vol..6, No.1, 2020

Doi: https://doi.org/10.24198/cosmogov.v6i1.24793

http://jurnal.unpad.ac.id/cosmogov/index

National Festival from the start of launching in 2017 to the present year 2018 in terms of better management. Starting from how to manage human resources, finance, marketing, and operations which from time to time continue to improve in order to provide appropriate quality and quantity of tourists who buy tickets online.

The development of Grebeg Suro and FNRP online tickets was quite rapid. At the time of the first year of online ticketing, Volunteer Grebeg Suro was given 8 days, at that time online tickets were sold +-850 seats. As for the 2018 grebeg suro, volunteers were given 4 working days.

Seats were sold at that time +-950 seats. Of course the development is very significant. The Grebeg Suro ordering application has also been the \# 1 application for the free ticket booking application category on the Google Play Store. The level of satisfaction of the people who bought tickets online was quite good. This was evident from some spectators who bought tickets online not only once, but several times.

Table 2. The Online and Regular Tickets

\begin{tabular}{|c|c|c|}
\hline Difference & Online Ticket & Regular Ticket \\
\hline Price & $\operatorname{Rp} 45.000-\operatorname{Rp} 130.000$ & Rp 5.000 and $\operatorname{Rp} 8.000$ \\
\hline facilities & Ponorogo Merchandise & no merchandise \\
\hline Service & $\begin{array}{l}\text { Private, Picked up from the } \\
\text { exchange barcode and sent } \\
\text { back to seats }\end{array}$ & $\begin{array}{l}\text { Tourists / audience not picked up } \\
\text { and not sent back to a seat }\end{array}$ \\
\hline Seating position & $\pm 10 \mathrm{~m}$ from the stage & $\pm 20 \mathrm{~m}$ until $\pm 50 \mathrm{~m}$ from the stage \\
\hline Chair & sofa & Zinc or Iron \\
\hline Payment & Via a bank transfer & Pay in place \\
\hline Contact Person & Ready & Not Have \\
\hline Options package & $\begin{array}{c}\text { Platinum, Gold, Silver, Bronze } \\
\text { Couple, and Bronze Group }\end{array}$ & Ekonomic and VIP Class \\
\hline How to get & Through the application & Queuing up at the counter \\
\hline Status & Online & Offline \\
\hline Information & Clear & unclear \\
\hline
\end{tabular}

Online tickets for Grebeg Suro and Reyog Ponorogo National Festival were very effective. Some assessment indicators include: the time spent, the convenience provided, and the education provided to the community. Online tickets through the Grebeg Suro application provided good information about the products offered.

Booking tickets online, allows volunteers to oversee the number of seats that have been sold every day and the results of income generated, so that the entry and exit of revenue becomes clear.
The audience felt helped by, related to the ticket booking process, especially the audience outside the area.

The public response to the existence of the Grebeg Suro online ticket and the Reyog Ponorogo National Festival was very positive. Many tourists or spectators appreciate the Grebeg Suro application. They feel no need to fret because they have to queue, because they only need to order online, exchange the barcode and will be delivered to their seats. 
Vol..6, No.1, 2020

Doi: https://doi.org/10.24198/cosmogov.v6i1.24793

http://jurnal.unpad.ac.id/cosmogov/index

Online tickets were considered very practical and efficient, so it was very useful for those who do not want to be "complicated". Through the data recorded in the video and the results of interview testimonials to online ticket consumers, it could be concluded that:

Online tickets were the smartest and best innovation in the organization of Grebeg Suro by providing classy services to tourists.

Online tickets provided satisfying facilities, because in addition to getting a strategic place, can bring souvenirs from Ponorogo Regency, online tickets also provide excellent service.

Table 3. Online and Conventional Tickets

\begin{tabular}{ccc}
\hline difference & Online & Conventional \\
\hline $\begin{array}{c}\text { Form } \\
\text { technology } \\
\text { Range }\end{array}$ & $\begin{array}{c}\text { Paperless } \\
\text { Uses Information Technology and } \\
\text { Artificial Intelligence (AI) } \\
\text { Brice }\end{array}$ & $\begin{array}{c}\text { The use of paper and ticket } \\
\text { Use manually and need a human } \\
\text { operator }\end{array}$ \\
& $\begin{array}{c}\text { More expensive beginning, but } \\
\text { save place, money, and time, after } \\
\text { that would be more efficient }\end{array}$ & $\begin{array}{c}\text { Cheaper, but not effective in, } \\
\text { proceeds and higher operating } \\
\text { costs }\end{array}$ \\
\hline & Source: Estimated from research conducted & Only can be accessed at one time, \\
\end{tabular}

Innovation in the management of E-Ticketing was a positive thing carried out by the organizer of the tourism agenda with the aim to overcome problems that often occur, such as: uneven ticket distribution, unclear ticket purchase process, nonstandard ticket prices, and others. The implementation of tourism activities in Ponorogo Regency with a breakthrough in managing E-Ticketing was very effective so that it could have a positive impact on the organization of tourism activity.
Online tickets were as an appropriate media in order to provide education to the public to make Ponorogo Regency a Smart City.

This online ticket was managed by Volunteer of Grebeg Suro and Reyog Ponorogo National Festival within full responsibility and totality, a group of young people who were innovative, young, to do innovation.

Simply, we could see the differences of tickets online and conventional, in several differences, such as: 
Vol..6, No.1, 2020

Doi: https://doi.org/10.24198/cosmogov.v6i1.24793

http://jurnal.unpad.ac.id/cosmogov/index

online tickets, volunteers could monitor how many seats were sold every day and how much revenue was generated.

\section{REFERENCES}

Agung, M. (2019, Oktober 1). Minimnya keterlibatan pemuda dalam acara Festifal Nasional Reyog Ponorogo. (T. Peneliti, Interviewer)

Alphonso, A., \& Eriyanti, F. (2019). Efektifitas Penerapan Pembayaran Tiket Elektronik pada Bus Trans Padang. Ranah Research, 174 182.

Azrina Mazlin Alias, V. B. (2016). Impak Kesukarelawanan dalam kalangan belia di Kuala Lumpur : Stau Kajian. Kepemimpinan Pendiidkan, 25-43.

Diantini, i. P., Sukidin, \& Hartanto, W. (2019).

Efektiftas

PenerapanMobile Aplication "KAI ACCES" oleh Konsumendi PT Kereta Api Indonesia Persero Daerah Operasi 9 Stasiun Jember. Jurnal Pendidikan Ekonomi, 132 137.

Indonesia, K. N. (2006). Buku Putih Penelitian Pengembangan dan Penerapan Ilmu Pengetahuan dan Teknologi Bidang Teknologi Informasi dan Komunikasi 2005 2025. Jakarta: Kementerian Negara Riset dan Teknologi Republik Indonesia.

J, M. (2005). Metode Penelitian Kualitatif. Bandung: Rosdakarya.

Jugiyanto. (2005). Sistem Teknologi Informasi. Yogyakarta: Andi.

Iwan, S. (2012). Agribisnis Kreatif Cetakan 1. Jakarta: Penebar Swadaya.

Jugiyanto. (2005). Sistem Teknologi Informasi. Yogyakarta: Andi.

Kusbandrijo, B., Tjahjono, E., \& Rochim, A. I. (2018). Pengelolaan Kawasan Wisata Terintegrasi di Kabupaten Ponorogo denganPendekatan City Marketing. DIA (Jurnal Administrasi Publik, 50 - 61.
The viewer felt helped, this was because the audience who bought tickets online were those from outside the city, making it easy to buy tickets for the show.

Mahmudi. (2005). Manajemen Kinerja Sektor Publik. Yogyakarta: UPP AMP YKPN.

Mutiarin, D. (2014). Manajemen Birokrasi Dan Kebijakan. Yogyakarta: Pustaka Pelajar.

Nawawi, H. (2003). Pengantar Penelitian Kualitatif. Jakarta: Rineka Cipta.

Nugroho, I. (2019, Oktober 1). Keikusertaan dalam kepanitiaan Grebeg Suro dan Festival Nasional Reyok Nusantara. (T. Peneliti, Interviewer)

Ramma Wisnu Dewantara, D. S. (2015). Ramma Wisnu Dewantara, Derajat S. Widhyharto. JSP, 40-52.

Rismayanti, F. A., Marjono, \& Umamah., N. (2017). "National Festival Reyog Ponorogo" As an Effort to Preserve Reyog Arts in Ponorogo Regency 1995-2016. Historica, $213-226$.

Siagian, I. C. (2014). Efektifitas tiket online berbasil Rail ticket system (RTS) di PT Kereta Api Indonesia (Persero) Daerah Operasi 8 Stasiun Besar Surabaya Gubeng. Publika, $1-10$

Siagian, S. P. (2001). Manajemen Sumber Daya Manusia. Jakarta: Bumi Aksara.

Sugiyono. (2010). Metode Penelitian Pendidikan Pendekatan Kuantitatif, Kualitatis dan $R \& D$. Bandung: Alfabeta.

Suhendra, A., \& Setiaputra, I. R. A. (2019). Intervensi Pemerintahan Daerah Dalam Membangun Inovasi Perdesaan Di Kabupaten Hulu Sungai Selatan Provinsi Kalimantan Selatan. Jurnal Kebijakan Pembangunan, 14(2), 147 - 156. Retrieved from http://jkpjournal.com/index.php/me nu/article/view/20

Sugiyono. (2012). Metode Penelitian Kualitatif. Bandung: ALFABETA. 
Vol..6, No.1, 2020

Doi: https://doi.org/10.24198/cosmogov.v6i1.24793

http://jurnal.unpad.ac.id/cosmogov/index

Sekapur, S. (2009). Makalah Sistem Informasi Manajemen Tentang $e$ ticketing. Retrieved from http://sekapursirihtravel.wordpress. com/2009/04/22/e-ticket/

Zaenudin, D. M. (2014). Manajemen Birokrasi dan Kebijakan. Yogyakarta: Pustaka Pelajar.

Antara news diakses

dari https://www.antaranews.com/berit a/1029512/pemkab-ponorogoadakan-festival-budaya-bumi-reog pada 06 Aril 2020

\section{ACKNOWLEDGEMENT}

We thank the Government Science Study Program, Faculty of Social and Political Sciences, Universitas Muhammadiyah Ponorogo, as an institution that provides support until the completion of this study, in addition we thank the Department of Tourism of the Regency of Ponorogo for providing data to complete this study until the end . 